Article

\title{
Earth Observation Systems and Pasture Modeling: A Bibliometric Trend Analysis
}

\author{
Lwandile Nduku ${ }^{1,2}{ }^{\oplus}$, Ahmed Mukalazi Kalumba ${ }^{1,2}{ }^{(0}$, Cilence Munghemezulu ${ }^{3}\left({ }^{\circ}\right.$,

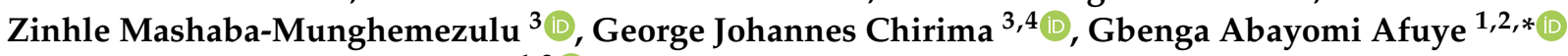 \\ and Emmanuel Tolulope Busayo ${ }^{1,2}$ (D)
}

Citation: Nduku, L.; Kalumba, A.M.; Munghemezulu, C.;

Mashaba-Munghemezulu, Z.; Chirima, G.J.; Afuye, G.A.; Busayo, E.T. Earth Observation Systems and Pasture Modeling: A Bibliometric Trend Analysis. ISPRS Int. J. Geo-Inf. 2021, 10, 793. https://doi.org/ 10.3390/ijgi10110793

Academic Editors:

Palaiologos Palaiologou and Kostas Kalabokidis

Received: 28 August 2021

Accepted: 12 November 2021

Published: 20 November 2021

Publisher's Note: MDPI stays neutral with regard to jurisdictional claims in published maps and institutional affiliations.

Copyright: (c) 2021 by the authors. Licensee MDPI, Basel, Switzerland. This article is an open access article distributed under the terms and conditions of the Creative Commons Attribution (CC BY) license (https:/ / creativecommons.org/licenses/by/ $4.0 /)$.
1 Department of Geography \& Environmental Science, University of Fort Hare, Alice 5700, South Africa; ndukulwandile@gmail.com (L.N.); AKalumba@ufh.ac.za (A.M.K.); etobusayo@yahoo.com (E.T.B.)

2 Geospatial Application, Climate Change \& Environmental Sustainability Lab-GACCES, University of Fort Hare, Alice 5700, South Africa

3 Geoinformation Science Division, Agricultural Research Council, Natural Resources and Engineering, Pretoria 0001, South Africa; MunghemezuluC@arc.agric.za (C.M.); MashabaZ@arc.agric.za (Z.M.-M.); ChirimaJ@arc.agric.za (G.J.C.)

4 Department of Geography, Geoinformatics \& Meteorology, University of Pretoria, Pretoria 0001, South Africa

* Correspondence: afuyeabayomi@gmail.com

Abstract: An Earth observation system (EOS) is essential in monitoring and improving our understanding of how natural and managed agricultural landscapes change over time or respond to climate change and overgrazing. Such changes can be quantified using a pasture model (PM), a critical tool for monitoring changes in pastures driven by the growing population demands and climate changerelated challenges and thus ensuring a sustainable food production system. This study used the bibliometric method to assess global scientific research trends in EOS and PM studies from 1979 to 2019. This study analyzed 399 published articles from the Scopus indexed database with the search term "Earth observation systems OR pasture model". The annual growth rate of $19.76 \%$ suggests that the global research on EOS and PM has increased over time during the survey period. The average growth per article is $n=74$, average total citations (ATC) $=2949$ in the USA, is $n=37$, $\mathrm{ATC}=488$, in China and is $n=22, \mathrm{ATC}=544$ in Italy). These results show that the field of the study was inconsistent in terms of ATC per article during the study period. Furthermore, these results show three countries (USA, China, and Italy) ranked as the most productive countries by article publications and the Netherlands had the highest average total citations. This may suggest that these countries have strengthened research development on EOS and PM studies. However, developing counties such as Mexico, Thailand, Sri Lanka, and other African countries had a lower number of publications during the study period. Moreover, the results showed that Earth observation is fundamental in understanding PM dynamics to design targeted interventions and ensure food security. In general, the paper highlights various advances in EOS and PM studies and suggests the direction of future studies.

Keywords: bibliometrics; climate change; EOS; PM; remote sensing

\section{Introduction}

Pastures are one of the most widespread terrestrial plant systems [1]. Pastures cover about $31.5 \%$ of the global land area and other land cover types such as farmland and managed grazing lands, thus making pastures predominant among nature's services [1,2]. Pastures are the second largest coverage of the Earth's surface and are also second in carbon dioxide sequestration from the atmosphere after forests [2-4]. Pastures are an important natural resource that supports plant growth and provide a cheap feed source for livestock production [5]. Consequently, the functions and benefits of pastures are associated with soil erosion protection, nutrient persistence, and are a habitat for animal 
biodiversity, among others [6,7]. Global studies suggested different trends in pastures dynamics [8-10]. Such studies estimate $40 \%$ of pasture degradation globally between 1982 and $2006[11,12]$. In Europe, pastures have undergone reductions in quality and quantity through the intensification of animal production over the past decades [13]. Eastern Spain, western Mediterranean Badlands, Loess Plateau of China, eastern Himalayas of India, Western Brazilian Amazon, and Slovakia have been affected by high soil erosion rates leading to the degradation of pastures and rangeland ecosystems [14-16]. Large areas in Australia, South America, India, and half of the pasture surface in Africa have experienced varying degrees of deterioration from grazing pressure and soil erosion [5,17-19]. Meanwhile, pastures suffer from poor farming methods and long-term grazing and unsustainable stocking levels in sub-Saharan Africa [20,21]. In southern Africa, pastures have been over-utilized for livestock production and are often associated with intensive agricultural production systems [22]. Consequently, the increasing rate of overgrazing is one of the leading factors in the degradation of pastures globally $[13,20]$. Therefore, continuous monitoring of pastures is crucial to track changes in grazing capacity and intensity in any given region.

Studies show that pastures are affected by different factors such as climate change, overgrazing, soil erosion, urbanization, mining, and land-use change [23-25]. These factors present multiple threats to livestock production, human society, vegetated ecosystem, and natural resource conservation $[5,24,26]$. Climate change projections indicate that pastures will experience extreme water shortage, heat stress, and prolonged growing seasons [27]. Global climate models (GCM) have predicted that the temperature is expected to increase from 1 to $1.25^{\circ} \mathrm{C}$ and may impede pasture growth across regions. Consequently, areas with rainfall deficits could experience a reduction in pasture productivity [28]. Weather parameters such as temperature and rainfall have significantly influenced pasture dynamics over the past decades [29]. Many studies have reported that overgrazing has threatened native vegetation and reduced soil infiltration thereby inhibiting pasture growth $[8,30]$. Soil erosion is one of the factors that reduces soil fertility, which facilitates pasture growth and development [16]. The expansion of built-up areas leads to the total loss of pasture areas [31]. A study reported that pollution from industrial, mining, and agricultural activities poses a significant impact on pasture conditions [32]. Meanwhile, intensive land-use change can also improve or degrade pasture areas [33]. Therefore, it is important to explore the existing literature and identify other influential factors that can contribute to pasture loss or degradation in a given region. On the other hand, pasture modeling based on the experimentation of monitoring the condition is short-lived and expensive. The breakthrough of Earth observation systems to monitor the Earth's surface provides optimal, timely, and cost-effective techniques for pasture modeling on large scales. Pasture model (PM) refers to an incremental change in time to monitor and assess pasture conditions in response to climate, urbanization, soil evaporation, overgrazing, runoff, and land-use change $[34,35]$. In general, pastures are monitored with the aid of conventional and remotely sensed techniques. Conventional techniques are used to determine pasture quality and require detailed sampling. However, this presents limited information about the spatial pattern of pasture dynamics. Limitations of conventional methods also include the high cost of laboratory analysis and are prone to human errors [36,37]. Remote sensing techniques are superior to conventional methods; they provided robust and time-effective solutions. The demonstration of the use of acquired remote sensing data and its suitability in monitoring grazing lands cannot be overemphasized with different use of satellite multisensors. Notable limitations of satellite remote sensing techniques are associated with big data assimilation in managing spectral and spatial resolutions over time. However, current advances in cloud computing and the launch of improved satellite sensors address these limitations. For instance, the recent advancements in Earth observation systems such as synthetic aperture radar (SAR) Sentinel-1 and optical imagery of Sentinel-2 are associated with improved spectral and spatial resolutions to monitor pasture change dynamics $[38,39]$. Remote sensing data have been efficiently used to predict pasture yields, herbage quality, 
productivity, and pasture quality parameters [40,41]. Therefore, it is important to appraise the evolutionary trends and identify current research hotspots to better understand the dominant themes by using the bibliometric method of published literature on EOS and PM studies.

Bibliometrics is a comprehensive statistical method used in evaluating published literature [42-46]. Generally, bibliometric analysis provides a clear understanding of published research articles on informative and objective scientific studies within a specified field of study [47-52]. Most studies used bibliometric analysis to identify gaps and advance the literature review in a specific niche area [53-60]. This study assessed global scientific research history on EOS and PM studies from 1979 to 2019. The study appraised published articles by assessing the annual scientific production, author's global citation, decadal trending topics, keywords co-occurrence network, journal analysis, institutions, and countries' collaboration on EOS and PM studies. The outcome of this study is fundamental in Earth observation systems by providing important information on pasture model dynamics for designing targeted interventions and ensuring food security.

\section{Data Collection, Preparation and Methods}

The Scopus indexed database provided adequate data to perform a bibliometric analysis on EOS and PM studies and to determine specific trends and identify knowledge gaps. The Scopus database was used to mine the data for this study on 2 October 2020, as presented in Table 1. The bibliometric analysis was carried out using bibliometric Rpackage (RStudio v4.0), biblioshiny [49,61,62] and VOSviewer software (v1.6.16) [63-65]. The application of these software provides a web interface for bibliometrix [66-69]. These are available open-source software. All publications related to EOS and PM research were searched using the search term ("Earth observation systems OR pasture model"), which include article title, abstract, and keywords from 1979 to 2019. The Boolean operation OR was used to combine the search terms. Therefore, the search terms generated a total of 1102 articles, including conference papers, articles, reviews, book chapters, conference reviews, short surveys, books, editorial, notes, and erratum, from the Scopus database. The search term was refined to 435 articles written in the English language and of review document type. The retrieved 435 articles were processed for data cleaning to identify duplications of articles without authors and affiliations using the Citation Analysis Package (CITAN) in the R repository [49,70]. Data cleaning is one of the basic steps in bibliometric analysis but is time-consuming. CITAN and biblioshiny packages were performed for the disambiguation process of identifying articles without authors and affiliation institutions [70]. Therefore, the study used a total of 399 articles for bibliometric analysis and interpretation. Consequently, the bibliometric method utilized for this study cannot generalize studies on EOS and PM using one database. The analyses were carried out based on published research articles to streamline and focus on published studies that explored EOS and PM to accommodate the niche area. To this end, the highlighted factors shaped the research direction of materials and methods explored and adopted in data collection and analysis. Figure 1 presents the graphical representation of data processing as shown below.

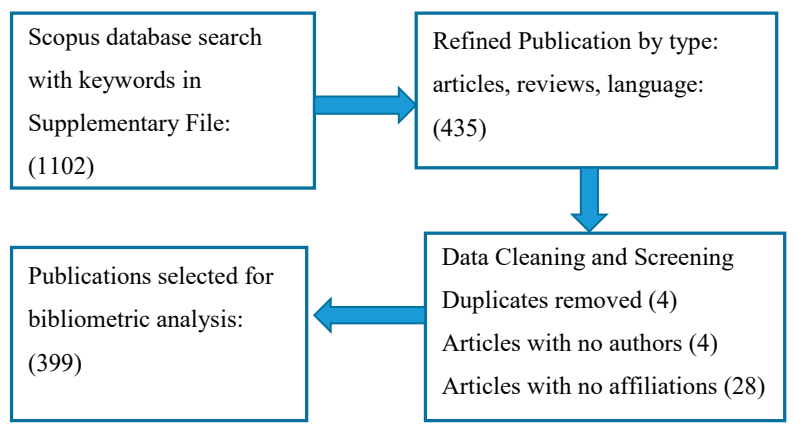

Figure 1. Graphical representation of data processing. 
Table 1. Main summary information retrieved on EOS and PM studies (1979-2019).

\begin{tabular}{cc}
\hline Description & Results \\
\hline Time Span & $1979-2019$ \\
Documents & 435 \\
Sources (Journals, Books, etc.) & 229 \\
Keywords Plus (ID) & 3279 \\
Author's Keywords (DE) & 1257 \\
Average Citations per Document & 19.76 \\
Authors & 1682 \\
Author Appearances & 2018 \\
Authors of Multi-Authored Documents & 1622 \\
Single-Authored Documents & 68 \\
Documents per Author & 0.259 \\
Authors per Document & 3.78 \\
Co-Authors per Document & 4.64 \\
Collaboration Index & 4.42 \\
Article & 402 \\
Review & 33 \\
\hline
\end{tabular}

\section{Results}

\subsection{Characteristics of Scopus Indexed Database}

The analysis includes 399 articles published and retrieved from the Scopus database with a focus on EOS and PM during the survey period. Accordingly, Table 1 summarizes the information retrieved from the Scopus database. For example, a collaborative index of 4.42 for 1682 authors have been revealed, with 1622 authors contributing to multi-authored documents and 68 authors of single-authored published documents, as shown in Table 1. The evaluation of journals, books, etc., includes 229 sources with 2018 authors appearances with 0.259 documents per author (3.78 authors per document) and 4.64 co-authors per document. The average annual percentage growth rate was $19.76 \%$ of citations per article recorded during the survey period.

\subsubsection{Temporal Scientific Contribution per Article}

The information in Figure 2 shows a relatively low annual production rate on the number of articles recorded from 1979 to 1993 . The notable decreasing trend in articles production rate started in 1980 and continued from 1984, 1990, 1992, 1994, 1997, 1999, 2001, 2006, 2009, 2010, 2013, and 2014, and a steady decrease was observed from 2018 and 2019, respectively. Furthermore, it is worth noting that the trend of publication peaked in some years and significantly decreased in some other years, particularly in 1981, 1990, 1997, and 2014, respectively, while the highest number of publications was observed in 2017. The study observed inconsistency in the publication trend rather than maintaining the same growth rate. During the survey period, an increased average citation per article was observed in 2019, reaching a maximum of $19.76 \%$. Consequently, the average citations per article declined, which connotes that the field of research was unstable in terms of average total citation per document [71].

\subsubsection{Scopus Global EOS and PM Most Cited and Spatial Distribution}

The information summarized in Table 2 shows the top 20 most cited countries on EOS and PM studies. The number of AAC and published articles varied across EOS and PM studies. However, 61 single-authored articles came from single country publications (SCP), while 13 joint authored articles came from multiple country publications (MCP). The USA ranked first among the top 20 countries based on published articles and total citations during the survey period. The USA accounts for 74 articles in terms of countries' contributions. It is worth noting that, among the most-cited countries, the USA had a total citation accounting for $(\mathrm{TC}=2949)$ and average article citations of $(\mathrm{AAC}) 39.85$, followed by the Netherlands $(\mathrm{TC}=1097$ and $\mathrm{AAC}=219.40)$ and France $(\mathrm{TC}=640$ and 
AAC $=45.71)$, respectively. Results show that most of the most cited studies came from developed countries, while a small number of cited studies came from developing countries such as Mexico, Thailand, Sri Lanka, and Brazil, among others. Consequently, there was a low research output from developing countries, which are characterized by a high level of self-funded or autonomous research and a language barrier [72]. The developed country's performance is measured in terms of most article citations, the highest number of publications, and their influence in the field among other developing countries. This implies that the publications of developed countries and the availability of research grants contributed to the increase in research productivity in the EOS and PM studies during the survey period $[73,74]$.

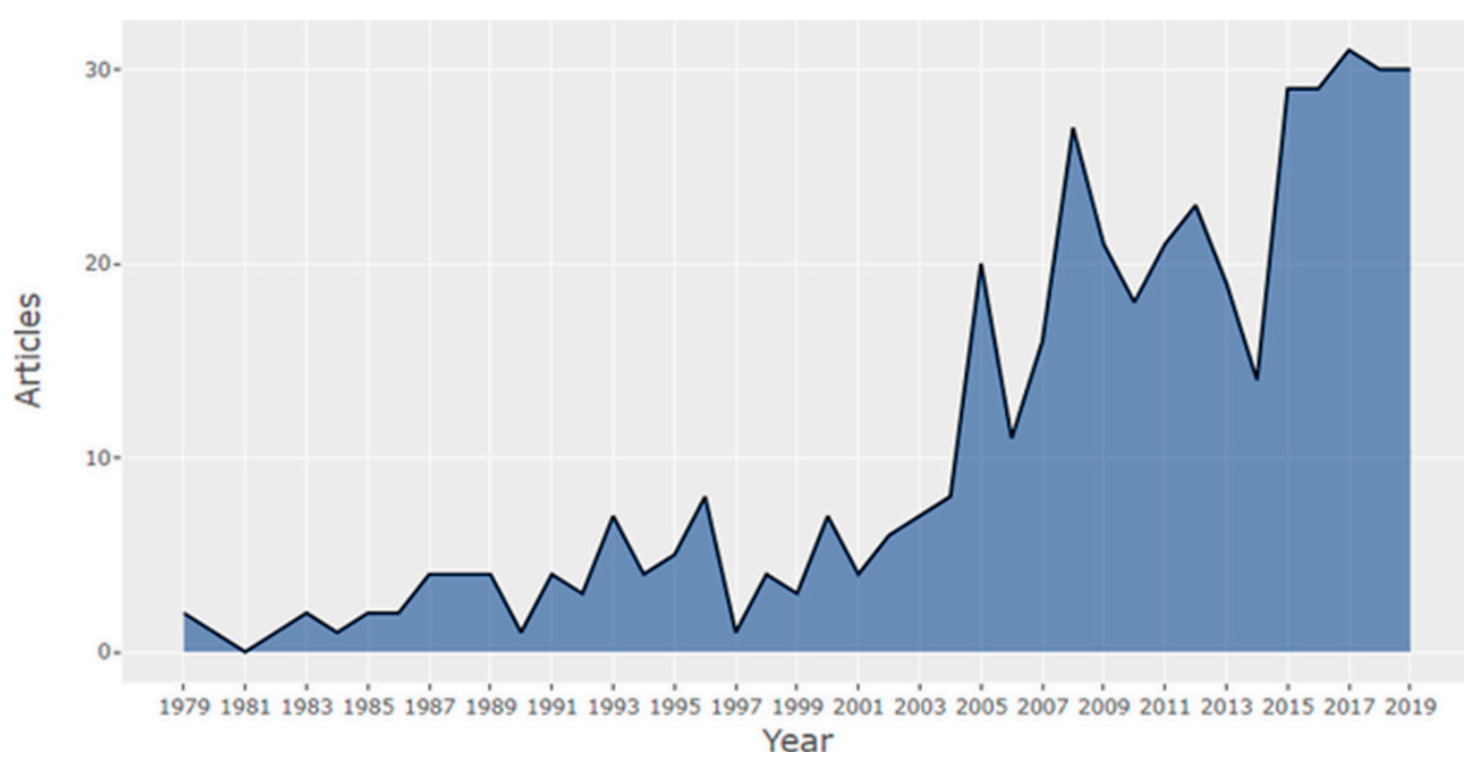

Figure 2. Annual scientific production on EOS and PM from 1979-2019.

\subsubsection{Scientific Collaboration Analysis per Countries}

Figure 3 shows the top 20 collaborations between countries that contributed to the EOS and PM studies. The bigger the node, the greater the country's dominance per article publication and the number of its associated links between different countries. The most dominant country was the USA, followed by China, France, Italy, Germany, and Japan, respectively. The country's influence in terms of its dominance may suggest the importance of strengthening research needs and collaboration networks to advance EOS and PM studies.

\subsubsection{Collaboration Analysis between Institutions}

Figure 4 shows the top 20 collaborations between various institutions that contributed to EOS and PM studies. Institutions with larger boxes and thicker connectors represent the strength of dominance in the field per article publication. Wuhan university, followed by the University of Chinese academy of sciences, University of Maryland, Institute of Remote Sensing and Digital Earth in China, California Institute of Technology, and NASA Goddard Spaceflight Center in the USA were amongst the most influential institutions on EOS and PM research. This suggests that scientific collaboration occurs mostly within national borders. The University of Geneva, University of Tokyo, Mississippi State University, Space Research Institute, and University of Defense Technology witnessed little or no publication on EOS and PM studies during the survey period. 
Table 2. Top 20 countries most cited per average article citation on EOS and PM from 1979-2019.

\begin{tabular}{|c|c|c|c|c|c|c|}
\hline Country & Articles & TC & AAC & SCP & МСР & $\mathrm{A} / \mathrm{MP}$ \\
\hline USA & 74 & 2949 & 39.85 & 61 & 13 & 0.176 \\
\hline Netherlands & 5 & 1097 & 219.40 & 0 & 5 & 1.000 \\
\hline France & 14 & 640 & 45.71 & 8 & 6 & 0.429 \\
\hline Italy & 22 & 544 & 24.733 & 10 & 12 & 0.545 \\
\hline China & 37 & 488 & 12.11 & 30 & 7 & 0.189 \\
\hline Germany & 14 & 281 & 20.07 & 10 & 4 & 0.286 \\
\hline Brazil & 2 & 192 & 96.00 & 1 & 1 & 0.500 \\
\hline Switzerland & 6 & 151 & 25.17 & 3 & 3 & 0.500 \\
\hline Canada & 5 & 149 & 29.80 & 3 & 2 & 0.400 \\
\hline $\begin{array}{l}\text { United } \\
\text { Kingdom }\end{array}$ & 5 & 118 & 23.60 & 2 & 3 & 0.600 \\
\hline Spain & 4 & 111 & 27.75 & 1 & 3 & 0.750 \\
\hline Japan & 14 & 83 & 5.93 & 11 & 3 & 0.214 \\
\hline Austria & 2 & 70 & 11.67 & 1 & 5 & 0.833 \\
\hline Mexico & 2 & 43 & 21.50 & 0 & 2 & 1.000 \\
\hline $\begin{array}{c}\text { New } \\
\text { Zealand }\end{array}$ & 2 & 41 & 20.50 & 2 & 0 & 0.000 \\
\hline Greece & 3 & 40 & 13.33 & 1 & 2 & 0.667 \\
\hline Thailand & 1 & 37 & 37.00 & 1 & 0 & 0.000 \\
\hline India & 8 & 36 & 4.50 & 8 & 0 & 0.000 \\
\hline Sri Lanka & 1 & 31 & 31.00 & 1 & 0 & 0.000 \\
\hline Poland & 4 & 23 & 5.75 & 4 & 0 & 0.000 \\
\hline
\end{tabular}

Note: Total citations (TC); average article citations (AAC); single country publications (SCP); multiple country publications (MCP); articles per million publications (A/MP).

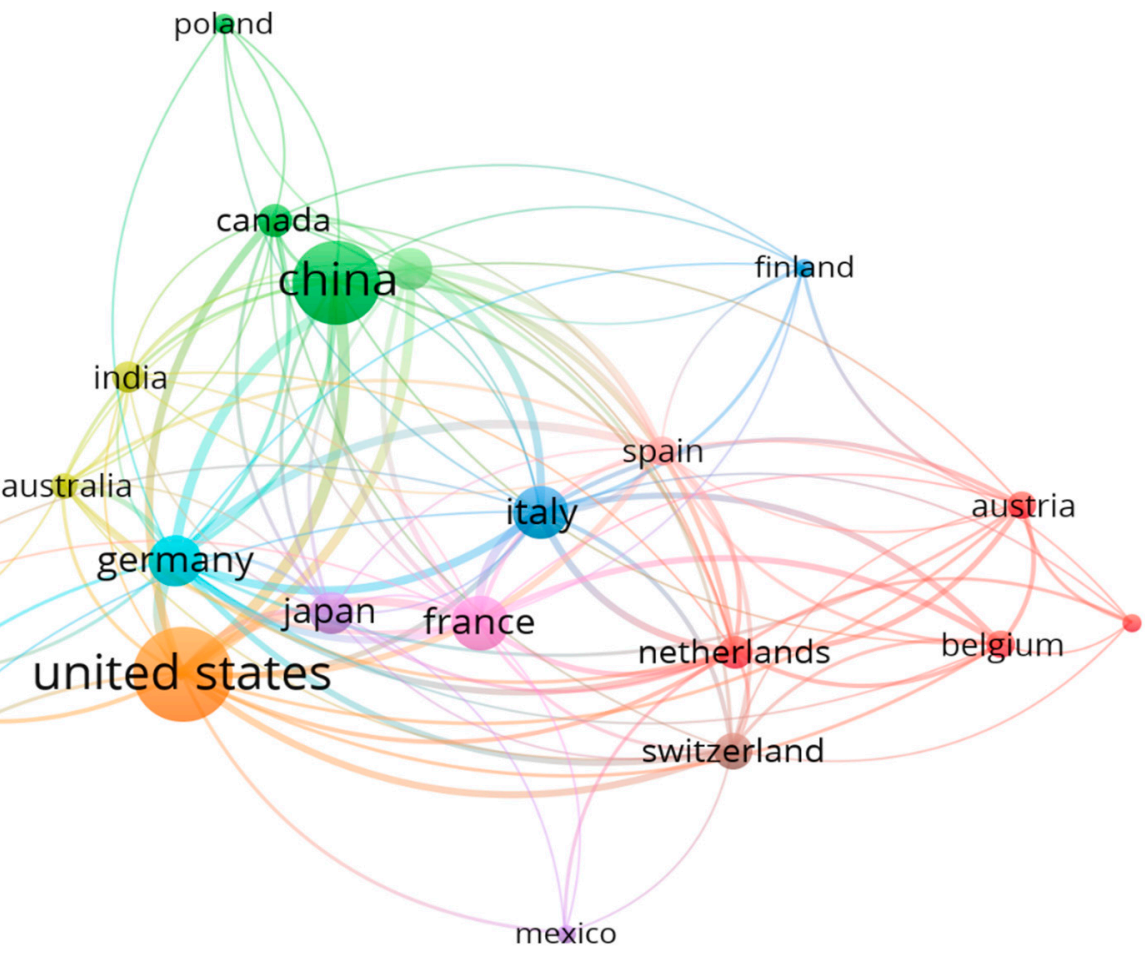

Figure 3. Top 20 Collaboration between Countries Network on EOS and PM Studies. 


\section{wuhan university}

\section{california institute of technology george mason university nasa goddard space flight center}

\section{university of maryland}

beijing normal university university of michigan joint research centre

institute for environment and sustainability

\section{institute of remote sensing and digital earth}

\section{university of chinese academy of sciences}

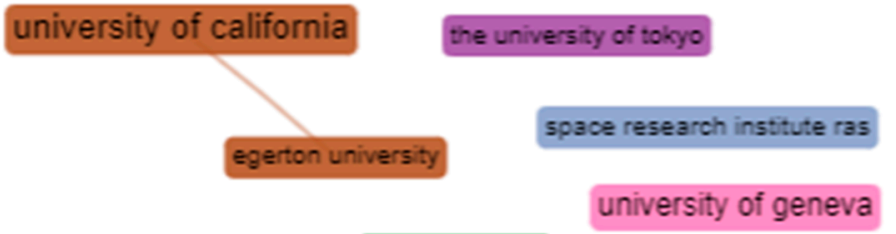

Figure 4. Top 20 Collaboration between institutions network on EOS and PM studies.

\subsubsection{Author's Contribution}

Figure 5 shows the top 20 global citations of authors' articles in EOS and PM studies. The results show that Drusch M., ranked the most cited author in the field, with the total number of articles accounting for TC $=1030$, followed Kaufman Y.J., accounting for $\mathrm{TC}=467$, and Duchemin B., accounting for TC $=262$, respectively. Drusch M. focused on the global monitoring environment, security for the European Commission, and European space agency on EOS and PM studies. Duchemin B., investigated the feasibility of using the normalized difference vegetation index (NDVI) derived from remote sensing data to provide indirect estimates of the leaf area index (LAI), a vital pasture parameter for the crop process model among others. Accordingly, the author's influence in terms of their productivity and the average total citation was centered on EOS and PM studies to measure the author's contribution in a specific field [75].

\subsubsection{Journal Analysis}

Information in Table 3 shows the top 20 Journals on EOS and PM studies. A total of 229 journals were published on EOS and PM during the survey period. The journal sources were ranked based on the number of most cited articles and each journal start year of publication on EOS and PM studies. IEEE Transaction on Geoscience and Remote Sensing, accounting for $(n=23)$ in 1987, followed by the Remote Sensing journal accounting for ( $n=14)$ in 1999, and Remote Sensing of Environment accounting for $(n=13)$ in 2010 had the highest number of articles, with $3.49 \%$ of the total. This may suggest that this field is relatively distributed through large journals and covers research erudition across many fields of study [46]. 


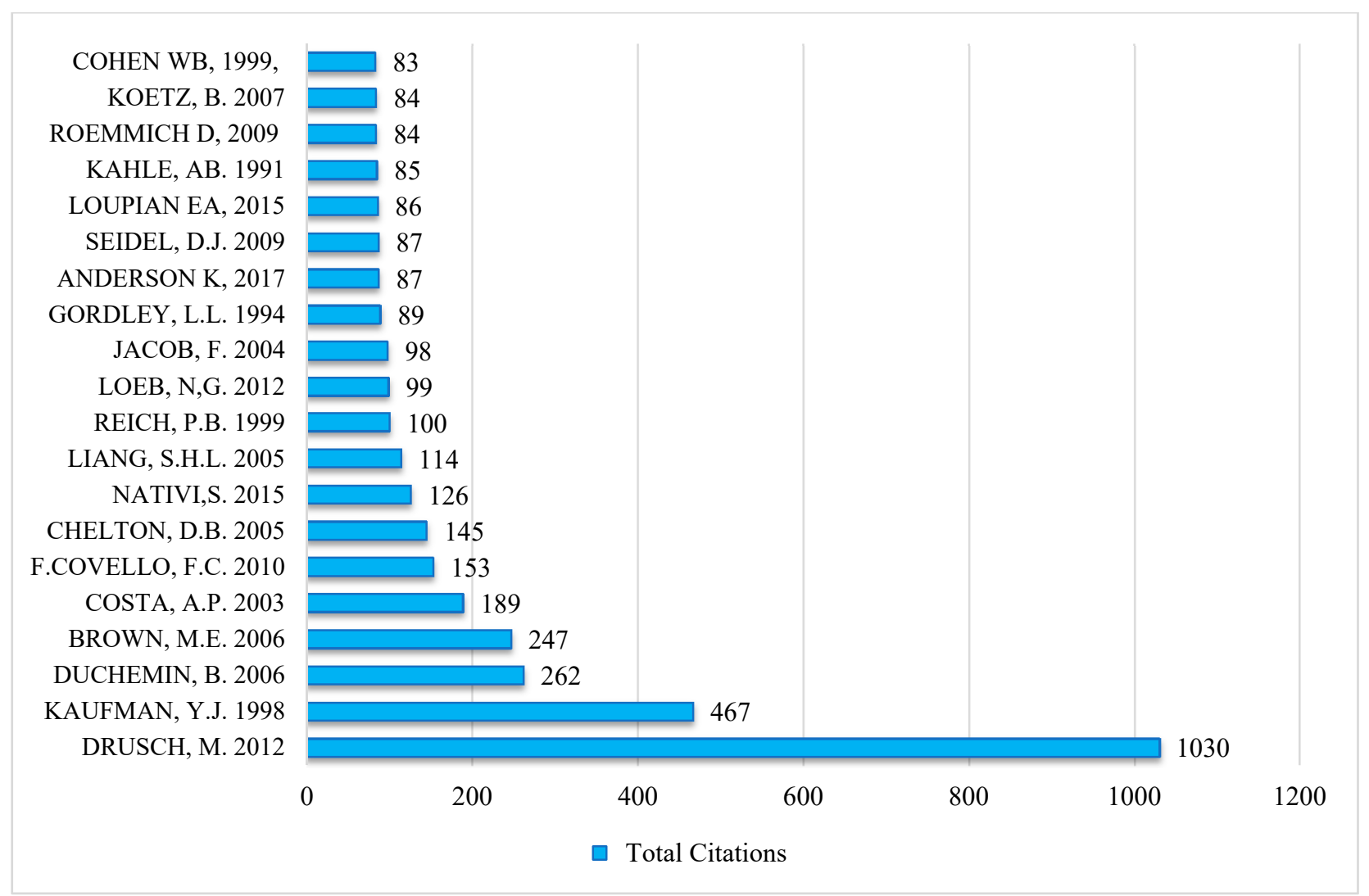

Figure 5. Top 20 global citations of authors on EOS and PM from 1979-2019.

\subsubsection{Top Global Cited Published Articles on EOS and PM Studies}

The information in Table 4 presents global top-cited articles on EOS and PM studies and summarizes findings explored using different satellites/EOS and models. The studies revealed a synergy between EOS and PM through change detection, satellite type, and algorithms trained and validated for PM. Most studies revealed positive outcomes for pasture models with high-resolution satellites such as Sentinel-2, LIDAR, GF-1, and others [76-78]. Some studies on pasture models showed negative results on EOS such as the Advanced Very High-Resolution Radiometer (AVHRR) and Moderate Resolution Imaging Spectroradiometer (MODIS). The multisensor data fusion process in EOS may improve the pasture model accuracy, which counters the low-resolution satellite sensors [76,79]. The constant development of Earth observation systems over the years has been inevitable in EOS and PM studies, such that EOS data utilized the normalized difference vegetation index (NDVI), enhanced vegetation index (EVI), and leaf area index (LAI) for calibration and validation of different models [80,81]. Most studies have used remote sensing data, algorithms, and in situ sampling methods to generate data for pasture models $[41,82]$.

Table 3. Top 20 journals on EOS and PM studies from 1979-2019.

\begin{tabular}{cccc}
\hline Source & NP & TC & Start Year \\
\hline IEEE Transaction on Geoscience and & 23 & 682 & 1987 \\
Remote Sensing. & 14 & 205 & 2010 \\
Remote Sensing. & 13 & 1688 & 1999 \\
Remote Sensing of Environment. & 12 & 159 & 2008 \\
IEEE Journal of Selected Topics in \\
$\begin{array}{c}\text { Applied Earth Observation and } \\
\text { Remote Sensing. }\end{array}$ & & & \\
\hline
\end{tabular}


Table 3. Cont.

\begin{tabular}{|c|c|c|c|}
\hline Source & NP & TC & Start Year \\
\hline IEEE Systems Journal. & 11 & 195 & 2008 \\
\hline Journal of Remote Sensing. & 11 & 93 & 2016 \\
\hline ACTA Astronautic. & 10 & 106 & 1987 \\
\hline Advances in Space Research. & 10 & 87 & 1994 \\
\hline $\begin{array}{c}\text { International Journal of Remote } \\
\text { Sensing. }\end{array}$ & 8 & 316 & 2000 \\
\hline $\begin{array}{l}\text { Proceedings of SPIE- the International } \\
\text { Society for Optical Engineering. }\end{array}$ & 7 & 27 & 1979 \\
\hline Space Policy. & 7 & 120 & 1995 \\
\hline Computers and Geosciences. & 6 & 176 & 2005 \\
\hline $\begin{array}{l}\text { International Journal of Applied Earth } \\
\text { Observation and Geoinformation. }\end{array}$ & 6 & 139 & 2009 \\
\hline Canadian Journal of Remote Sensing. & 5 & 103 & 1997 \\
\hline $\begin{array}{c}\text { Journal of Geophysical Research } \\
\text { Atmospheres. }\end{array}$ & 5 & 607 & 1998 \\
\hline $\begin{array}{l}\text { Current Problems in Remote Sensing } \\
\text { of the Earth from Space. }\end{array}$ & 5 & 109 & 2015 \\
\hline $\begin{array}{c}\text { Environmental Modelling and } \\
\text { Software. }\end{array}$ & 4 & 188 & 2013 \\
\hline $\begin{array}{l}\text { IEEE Geoscience and Remote Sensing } \\
\text { Letters. }\end{array}$ & 4 & 69 & 2005 \\
\hline Journal of Atmospheric Science. & 4 & 109 & 2000 \\
\hline Sensors (Switzerland). & 4 & 29 & 2017 \\
\hline
\end{tabular}

Note: Number of articles (n); total citations (TC).

Table 4. Top 15 globally cited articles on EOS and PM studies from 1979-2019.

\begin{tabular}{|c|c|c|c|}
\hline Satellite/EOS/Model & Findings/Gaps & Total Citation & Reference \\
\hline Sentinel-2 & $\begin{array}{l}\text { The findings reveal the } \\
\text { effectiveness of using } \\
\text { Sentinel-2 in a global } \\
\text { monitoring environment but } \\
\text { unable to retrieve previous } \\
\text { decades' data for a long time } \\
\text { series. }\end{array}$ & 1030 & [77] \\
\hline MODIS & $\begin{array}{l}\text { The results show that MODIS } \\
\text { products work better than } \\
\text { AVHRR in monitoring global } \\
\text { fire detection changes in the } \\
\text { location and rate of biomass } \\
\text { consumption by fires. }\end{array}$ & 467 & [83] \\
\hline $\begin{array}{l}\text { Landsat7-ETM+ images, } \\
\text { NDVI, LAI, AET, } \mathrm{ET}_{o}\end{array}$ & $\begin{array}{c}\text { Findings demonstrate } \\
\text { exponential relationships } \\
\text { between LAI and NDVI, as } \\
\text { well in LAI and plant } \\
\text { transpiration coefficient }\left(K_{\mathrm{cb}}\right) \text {; } \\
\text { good accuracy linear } \\
\text { relationship on NDVI and } K_{\mathrm{cb}} \\
\text { to wheat phenology in the } \\
\text { seasonal land cover using } \\
\text { Landsat data. Such analysis } \\
\text { approaches on a regional scale } \\
\text { are limited by high resolution } \\
\text { and visit time. }\end{array}$ & 262 & [80] \\
\hline
\end{tabular}


Table 4. Cont.

\begin{tabular}{|c|c|c|c|}
\hline Satellite/EOS/Model & Findings/Gaps & Total Citation & Reference \\
\hline $\begin{array}{c}\text { AVHRR, SPOT-Vegetation, } \\
\text { SeaWiFS, MODIS, Landsat } \\
\text { ETM+. NDVI }\end{array}$ & $\begin{array}{l}\text { Findings reveal a consistency } \\
\text { in NDVI records derived in } \\
\text { different satellites through } \\
\text { statistical and correlation } \\
\text { analyses for monitoring the } \\
\text { surface vegetation. }\end{array}$ & 247 & [76] \\
\hline COSMO-SkyMed & $\begin{array}{c}\text { Findings show } \\
\text { COSMO-SkyMed } \\
\text { constellation contribution of } \\
\text { the X-band SAR, fast response, } \\
\text { and short revisit time for } \\
\text { various agriculture } \\
\text { monitoring applications. }\end{array}$ & 153 & {$[84]$} \\
\hline $\begin{array}{l}\text { Global Earth Observation } \\
\text { System of Systems }\end{array}$ & $\begin{array}{l}\text { The findings reveal the } \\
\text { importance of knowledge and } \\
\text { semantic formalization to } \\
\text { address multidisciplinary } \\
\text { applications (i.e., pasture } \\
\text { change detection over time). }\end{array}$ & 126 & [85] \\
\hline NASA Sensor Web & $\begin{array}{l}\text { The findings showed the } \\
\text { development of GeoSWIFT } \\
\text { for the integration of remote } \\
\text { sensing imagery and real-time } \\
\text { in situ sensing observations of } \\
\text { crop yielding. }\end{array}$ & 114 & [86] \\
\hline $\begin{array}{l}\text { Earth Observation System, } \\
\text { MODIS, Land Science Team } \\
\text { model, LAI }\end{array}$ & $\begin{array}{l}\text { The results show the } \\
\text { combination of remote } \\
\text { sensing data with } \\
\text { process-based and spatially } \\
\text { distributed biogeochemistry } \\
\text { models to examine variation } \\
\text { in ecosystem processes. } \\
\text { However, these process } \\
\text { models can be validated } \\
\text { against direct measurements } \\
\text { made with eddy covariance } \\
\text { flux towers and ground-based } \\
\text { NPP sampling. }\end{array}$ & 100 & [87] \\
\hline $\begin{array}{l}\text { ASTER and MODIS. TES } \\
\text { algorithm, TISIE algorithm }\end{array}$ & $\begin{array}{l}\text { The results reveal the } \\
\text { feasibility of merging ASTER } \\
\text { and MODIS data for } \\
\text { emissivity and radiometric } \\
\text { temperature in semi-arid } \\
\text { rangelands and agricultural } \\
\text { areas. }\end{array}$ & 98 & [79] \\
\hline Earth Observations & $\begin{array}{l}\text { The findings show the } \\
\text { significant role of Earth } \\
\text { observation systems in } \\
\text { supporting the } 2030 \text { Agenda } \\
\text { directly addressing the } \\
\text { sustainable development } \\
\text { goals (SDGs). }\end{array}$ & 87 & [88] \\
\hline
\end{tabular}


Table 4. Cont.

\begin{tabular}{|c|c|c|c|}
\hline Satellite/EOS/Model & Findings/Gaps & Total Citation & Reference \\
\hline $\begin{array}{c}\text { Advanced Spaceborne } \\
\text { Thermal Emission Reflectance } \\
\text { Radiometer }\end{array}$ & $\begin{array}{l}\text { Findings demonstrate the } \\
\text { ability of ASTER to provide } \\
\text { science objectives identified } \\
\text { by the EOS global change } \\
\text { program such as surface } \\
\text { reflected radiances and the } \\
\text { application of digital elevation } \\
\text { models for vegetation } \\
\text { conditions. }\end{array}$ & 85 & [89] \\
\hline $\begin{array}{c}\text { LIDAR, Imaging spectrometer, } \\
\text { Radiative transfer models, } \\
\text { LAI }\end{array}$ & $\begin{array}{l}\text { The findings specified robust } \\
\text { estimates of the characteristics } \\
\text { of the forest canopy } \\
\text { characteristics that were } \\
\text { achieved, ranging from } \\
\text { maximal tree height, } \\
\text { fractional cover (Fcover), leaf } \\
\text { area index (LAI) to the foliage } \\
\text { chlorophyll, and water } \\
\text { content of the foliage for a } \\
\text { wide range of pastures. }\end{array}$ & 84 & [81] \\
\hline MODIS, LAI & $\begin{array}{l}\text { The findings validate land } \\
\text { cover and land use change } \\
\text { models using MODIS data } \\
\text { based on MODIS Land } \\
\text { Discipline Group } \\
\text { (MODLAND). }\end{array}$ & 83 & [90] \\
\hline $\begin{array}{c}\text { Environmental Mapping and } \\
\text { Analysis Program (EnMAP) } \\
\text { mission }\end{array}$ & $\begin{array}{l}\text { Findings revealed the } \\
\text { simulated tool of remote } \\
\text { sensing images for } \\
\text { hyperspectral and } \\
\text { multispectral data called } \\
\text { EnMAP to applications such } \\
\text { as pasture monitoring. }\end{array}$ & 77 & [91] \\
\hline $\begin{array}{l}\text { Widefield view (WFV for } \\
\text { GF-1), Prospect + Sail } \\
\text { radiative transfer model }\end{array}$ & $\begin{array}{l}\text { Findings show a high-quality } \\
\text { fractional vegetation cover } \\
\text { estimation algorithm using a } \\
\text { physical model and neural } \\
\text { networks through the first } \\
\text { high-resolution EOS Chinese } \\
\text { satellite (GF-1 data). }\end{array}$ & 74 & [78] \\
\hline
\end{tabular}

\subsubsection{Top 20 Authors Keywords and Co-Occurrence Network}

The information in Table 5 shows the top 20 authors' keywords on EOS and PM during the survey period. The author keywords were classified according to the author keyword (DE) and keyword Plus (ID). Remote sensing was ranked first and appeared most as a keyword term of the author (DE), accounting for $n=34$, followed by Earth observation $(n=20)$ and global Earth observation systems (GEOSS) $(n=18)$, respectively. Remote sensing had the highest appearance in author keyword Plus (ID), accounting for $n=171$, Earth observation accounting for $n=98$, and EOS accounting for $(n=76)$, respectively. Accordingly, Earth observation and remote sensing revealed dominance in authors' keywords (DE) and keyword Plus (ID). However, these keyword terms indicate that Earth observation applications have been central in remote sensing and global change detection. In addition, remote sensing, Earth observation, climate change, and MODIS appeared more between the author's keyword (DE) and keyword Plus (ID). This may suggest that these variables highlight the relationship between remote sensing and Earth 
observation system in monitoring and modeling pasture dynamics under global change [92]. However, Sentinel-2, agriculture, big data, and mathematical model were rarely used in authors' keywords in EOS and PM research, which may suggest more studies for future development.

Table 5. Top authors keywords used on EOS and PM studies from 1979-2019.

\begin{tabular}{|c|c|c|c|c|}
\hline Rank & $\begin{array}{c}\text { Author } \\
\text { Keywords (DE) }\end{array}$ & Articles & $\begin{array}{c}\text { Author } \\
\text { Keywords (ID) }\end{array}$ & Articles \\
\hline 1 & Remote sensing & 34 & Remote sensing & 171 \\
\hline 2 & $\begin{array}{c}\text { Earth } \\
\text { observation }\end{array}$ & 20 & $\begin{array}{c}\text { Earth } \\
\text { observation }\end{array}$ & 98 \\
\hline 3 & Geoss & 18 & EOS & 76 \\
\hline 4 & NDVI & 9 & Observations & 71 \\
\hline 5 & Climate change & 8 & Satellite imagery & 62 \\
\hline 6 & Interoperability & 8 & Satellites & 54 \\
\hline 7 & Satellite & 7 & Earth (planet) & 42 \\
\hline 8 & Geoss & 6 & Geoss & 40 \\
\hline 9 & MODIS & 6 & $\begin{array}{c}\text { Earth } \\
\text { observations }\end{array}$ & 31 \\
\hline 10 & Data sharing & 5 & Radiometers & 31 \\
\hline 11 & Monitoring & 5 & Satellite data & 31 \\
\hline 12 & Sentinel-2 & 5 & MODIS & 28 \\
\hline 13 & Agriculture & 4 & Calibration & 27 \\
\hline 14 & AMSR-E & 4 & Climate change & 27 \\
\hline 15 & Aster & 4 & Decision Making & 24 \\
\hline 16 & Big data & 4 & $\begin{array}{l}\text { Spatial } \\
\text { resolution }\end{array}$ & 24 \\
\hline 17 & Biodiversity & 4 & $\begin{array}{l}\text { Environmental } \\
\text { monitoring }\end{array}$ & 23 \\
\hline 18 & Calibration & 4 & Orbit & 21 \\
\hline 19 & Classification & 4 & $\begin{array}{l}\text { Weather } \\
\text { forecasting }\end{array}$ & 21 \\
\hline 20 & $\begin{array}{c}\text { Data } \\
\text { management }\end{array}$ & 4 & $\begin{array}{l}\text { Mathematical } \\
\text { model }\end{array}$ & 20 \\
\hline
\end{tabular}

Figure 6 shows the top 20 keywords' co-occurrence in EOS and PM studies. The size of nodes depicts the frequency of keywords. The larger the size of the node, such as remote sensing and Earth observation, the higher the frequency of keywords. Soil moisture, agriculture, land cover, environmental management, and rain (precipitation) are the most common factors used as keywords and are influential in the field of EOS and PM studies. Other important variables, such as soil, leaf area index, drought, and temperature, among others, had a low frequency of keywords, suggesting more research for future development in EOS and PM studies.

\subsubsection{Decadal Trending Topics of High-Frequency Keywords}

Figure 7 shows the trending topics over the last decade in the EOS and PM studies. The decadal trending topics were generated based on the trending topics associated with the high frequency of the author's keyword in the field during the survey period. The frequency of authors' keywords on EOS and PM was summarized within the period of the analysis by a structured scheme to classify the core high-frequency keywords with a word frequency greater than or equal to 10 being selected. Therefore, 12 high keywords were obtained in terms of their occurrence in the field and drawn as decadal trending topics, as shown in Figure 7. This depicts the keywords and areas to identify in EOS and PM studies. It is worth noting that trending topics such as climate change, Earth observation, NDVI, remote sensing, MODIS, and Sentinel-2, among others have been included under EOS and PM studies. Accordingly, remote sensing was observed at the highest peak in terms of its frequent applications in EOS and PM studies during the survey period. In addition, it was 
observed that, between the years 2008 and 2018, EOS and PM studies gained increased global attention and significance in space-based technology and development in modeling pasture dynamics.

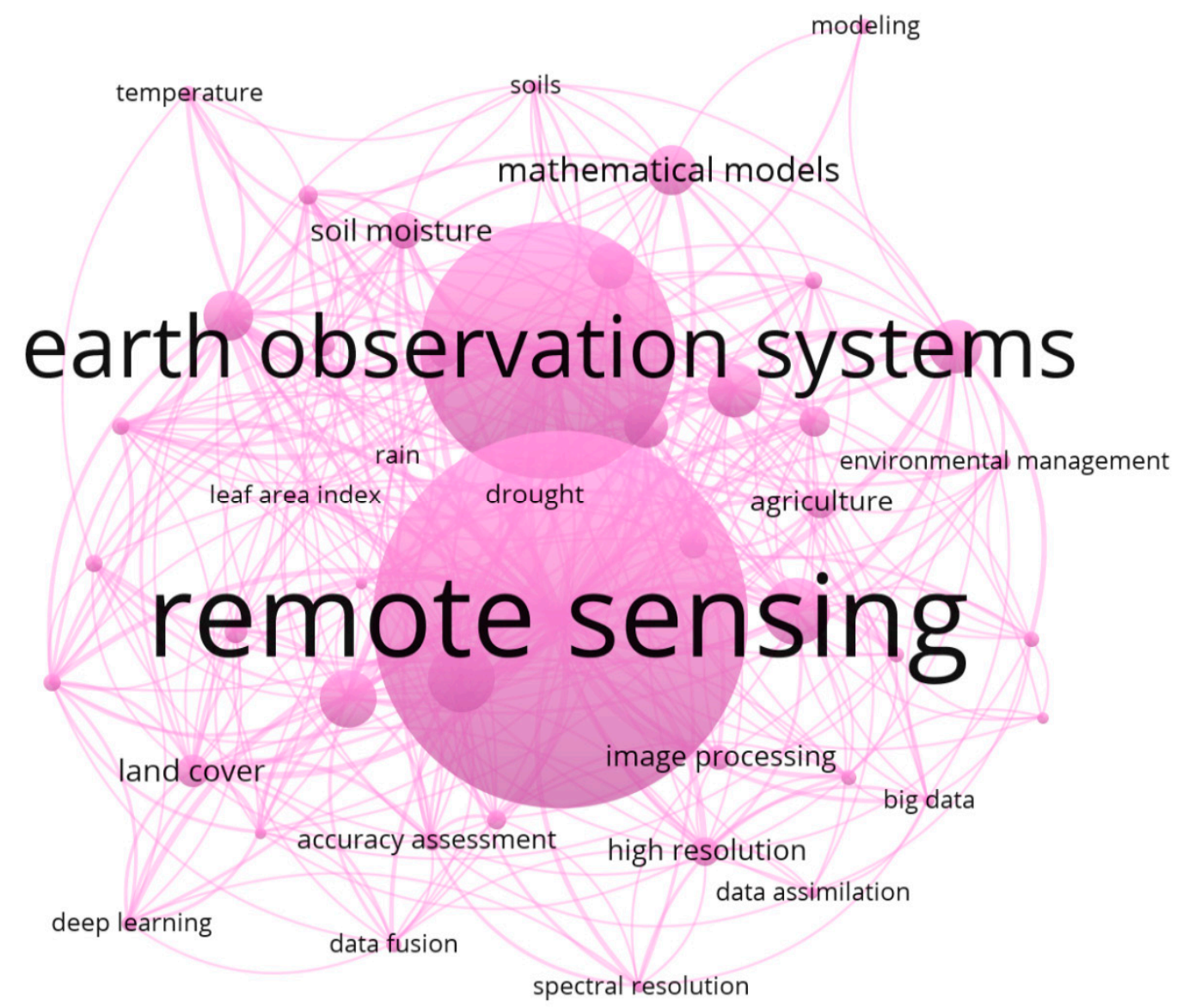

Figure 6. Top 20 keywords' co-occurrence network on EOS and PM studies.

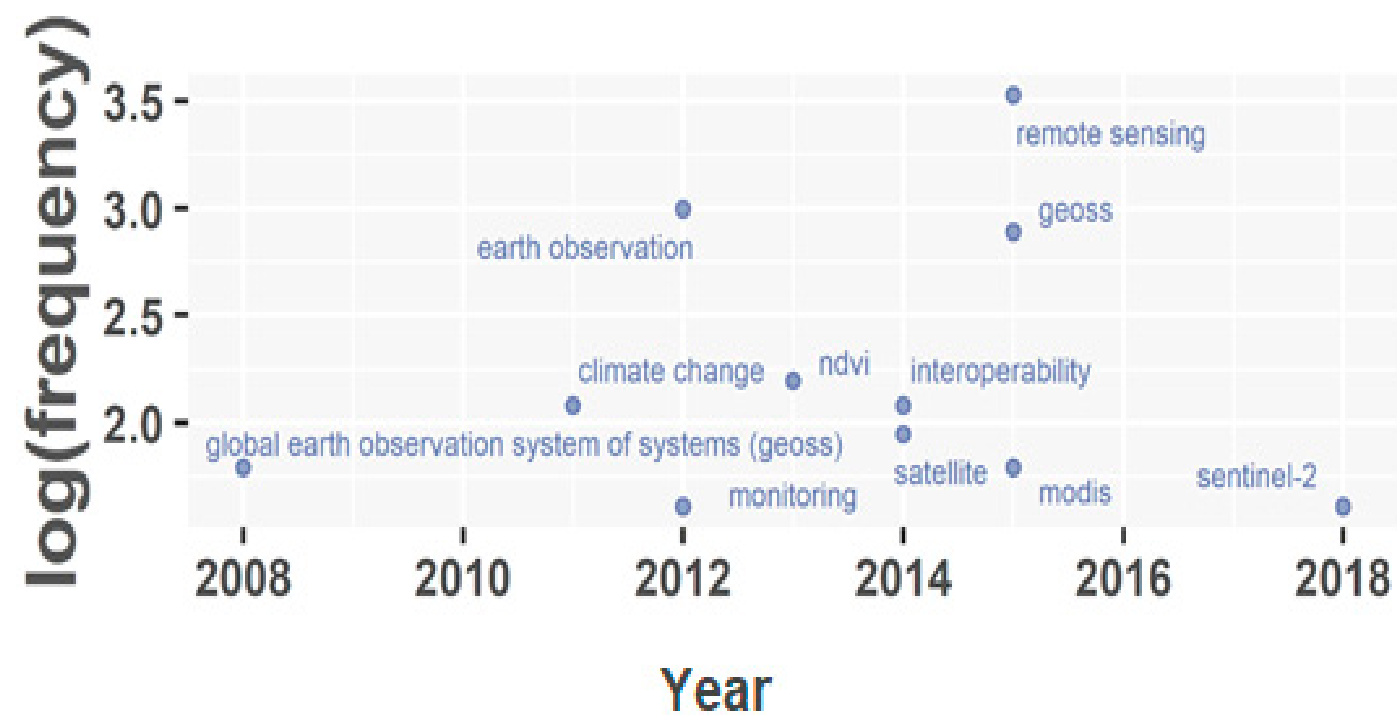

Figure 7. Decadal trending topics on EOS and PM studies. 


\section{Discussion}

This study assessed a total of 399 published articles on EOS and PM studies, using the bibliometric method. A detailed analysis was carried out to evaluate the annual scientific production, author's contribution, top global cited published articles, author's keyword, trending topics, and co-occurrence of keywords in EOS and PM studies. The average growth per article of EOS and PM research showed inconsistency during the survey period, which suggests that the field was unstable in terms of average total citations per article. The observed decline in publication of EOS and PM studies between 1980 and 2019 cannot be generalized in terms of countries' publications. This may be linked with complex data structures, limited large-scale high-resolution sensors, and the lack of EOS designed for PM studies [40]. The highest average citation per article was 19.76\%, suggesting that global research on EOS and PM has been increasing over the last decade, particularly between 2008 and 2018. The gradual increase in annual scientific production rate and average total citations on EOS and PM research resulted in increased production in terms of the number of publications and total citations per year over time. Progress in EOS and PM studies was at its highest peak in 2017 in terms of the number of publications, thus revealing the impact of recent EOS with an improved resolution for pasture modeling [41,93,94]. The results show that the USA, China, and Italy ranked the most cited and most productive authors in terms of average total citations and multiple country publications, which strengthened the research development in EOS and PM studies. Mexico, Thailand, Sri Lanka, Brazil, and other African nations had a low research output and single country publications on EOS and PM studies during the survey period. This reveals the need for these nations with low engagement to collaborate with nations in the global north to boost their research in EOS and PM to bolster the current food security initiatives. Furthermore, it is revealed that the USA developed the environment vulnerability decision technology (EVDT) to support environmental management decision-making and reduce the dual needs of processing data for monitoring surface changes on pasture dynamics $[95,96]$. Therefore, this justifies the USA's advance in EOS and PM, which depicts the country's advancement in space-based technology. Additionally, the USA has been at the center in recent spatiotemporal index developments for accelerating access to EOS big data assimilation to better understand Earth system and PM research [97]. This development may suggest that the author's keywords and the leading country's contribution to EOS and PM studies are an eye-opener to make room for other developing nations. Studies revealed that the Earth observation system race often varies between the USA, Europe, Asia, and North America in terms of advances in Earth observation and geoinformation science and technology $[98,99]$. The lack of investment in Earth observation systems for environmental monitoring decision-making could suggest the low publication rate for other developing countries on EOS and PM studies [99]. Remote sensing was observed to be the most appeared keyword in the field of EOS and PM studies. This is a demonstration that the contribution of remote sensing applications since 1978 in ecological research advances the synergy between EOS and PM studies $[100,101]$. This may have also contributed to the development of space-based technology and data assimilation techniques suitable for pasture modeling [41,102]. Furthermore, free access to EOS, such as Sentinel, Landsat, and MODIS, among others, contributed to pasture model research in terms of their applications to pasture management [80]. The use of remote sensing has the potential to influence policy makers to incorporate the use of remote sensing for strategic planning and minimize the impact of pasture degradation. The results of this study revealed the limitations of low-resolution satellite sensors such as AVHRR, Landsat, and MODIS, among others. However, these limitations might have affected the monitoring assessment of pasture modeling research on EOS and PM. Results further revealed that a series of authors' keyword terms and keywords' co-occurrence network help to identify factors such as soil moisture, climate change, and precipitation, among others affecting pasture dynamics in EOS and PM studies. However, the use of the author's keyword terms such as monitoring, Sentinel-2, agriculture, big data, and mathematical model has been scantly explored in EOS and PM studies. This may also suggest the recent development in 
European Union (EU) programs and sentinel missions, including statistical models and machine learning to monitor pasture dynamics at multiple scales $[9,41]$.

\section{Conclusions}

This study evaluated studies on EOS and PM to reveal the evolution and current research hotspot and better understand the dominant themes by using the bibliometric method to analyze published articles from 1979 to 2019. The findings in this study would help to advance the understanding of evolutionary trends of these studies by assessing the intellectual domain and identifying the history of global scientific research history in EOS and PM studies. Furthermore, the study appraised published articles by assessing the annual scientific production, author's global citation, decadal trending topics, keywords' co-occurrence network, journal analysis, and institutions' and countries' collaboration associated with EOS and PM studies. Therefore, using these available articles on EOS and PM helps to identify the research gap. The reviewed studies were used to evaluate and determine the current research hotspots and dominant themes, considering the information from time-varying trends observed in EOS and PM during the study period. The important scientific findings from these studies show that Earth observation systems and remote sensing are in the central position in all keywords with the largest significant appearance in the field. This connotes that future studies must appraise how far the EOS has been able to contribute to the advancements of modeling pasture dynamics. Earth observation systems play an important role in pasture monitoring and development using remote sensing techniques for mapping and assessing degraded land. Advances in artificial intelligence, deep and machine learning may compensate for the assessment of big ensemble data assimilation using mathematical algorithms for future EOS and PM studies. The key findings are associated with the application of pasture modeling, as Earth observation systems provided important information of time-series satellite imagery associated with change detection of terrain characteristics of pastoral rangelands. This information may help to spatially delineate anomalies in pastoral conditions, as well as growth and development in both length and intensity at different temporal and spatial scales. Therefore, bibliometrics has been widely utilized as a methodological approach to evaluate various research niche areas over time. Consequently, the study provided information for individuals, institutions, and governments in understanding the current state of research on EOS and PM. The results of this study are crucial in planning and managing pastoral rangelands and forest ecosystems. This also serves as an eye-opener for those developing countries, especially African nations, who had little or no research on EOS and PM studies and to provide hints for future research. This article suggests that various research databases should be incorporated to identify other possible research developments within the area of focus.

Author Contributions: Conceptualization, Lwandile Nduku; methodology, Lwandile Nduku; writingoriginal draft preparation, Lwandile Nduku; writing - review and editing, Gbenga Abayomi Afuye, Zinhle Mashaba-Munghemezulu and Emmanuel Tolulope Busayo; supervision, Ahmed Mukalazi Kalumba, Cilence Munghemezulu and George Johannes Chirima. All authors have read and agreed to the published version of the manuscript.

Funding: This research received funding from the National Research Foundation (grant number: TTK200221506319), University Fort Hare, Alice, Eastern Cape Province, South Africa.

Data Availability Statement: Data used in this study are available on request. Requests for access to these data should be made to Gbenga Abayomi Afuye: afuyeabayomi@gmail.com.

Acknowledgments: The bibliometric data used in this study are from the Scopus database. The authors thank the National Research Foundation (NRF) and University Fort Hare, South Africa, for the funding of this research and creating an enabling environment for research and to anonymous reviewers for their wonderful insights that strengthened this paper.

Conflicts of Interest: The authors declare no conflict of interest. 


\section{References}

1. Latham, J.; Cumani, R.; Rosati, I.; Bloise, M. Global Land Cover Share (Glc-Share) Database Beta-Release Version 1.0-2014; FAO: Rome, Italy, 29 April 2014. Available online: https://www.fao.org/uploads/media/glc-share-doc.pdf (accessed on 15 October 2021).

2. Ali, I.; Cawkwell, F.; Dwyer, E.; Barrett, B.; Green, S. Satellite remote sensing of grasslands: From observation to management. J. Plant Ecol. 2016, 9, 649-671. [CrossRef]

3. Franzluebbers, A.J. Soil organic carbon in managed pastures of the southeastern United States of America. Grassland Carbon Sequestration: Management, Policy and Economics. Integr. Crop Manag. 2010, 11, 163-175.

4. Afuye, G.A.; Ojeh, V.N. Temporal Variations in Ambient Carbon Monoxide Concentrations between Weekdays and Weekends in Akure Central Business District, South West Nigeria. Phys. Sci. Int. J. 2017, 16, 1-12. [CrossRef]

5. Letsoalo, N.L. Rangeland Management Practices among Emerging Livestock Farmers in Gauteng Province, South Africa. Available online: https:/ / uir.unisa.ac.za/handle/10500/25597 (accessed on 1 October 2021).

6. Yang, X.; Guo, X.; Fitzsimmons, M. Assessing light to moderate grazing effects on grassland production using satellite imagery. Int. J. Remote Sens. 2012, 33, 5087-5104. [CrossRef]

7. Cadman, M.; de Villiers, C.; Lechmere-Oertel, R.; McCulloch, D. Grasslands Ecosystem Guidelines: Landscape interpretation for planners and managers. In South African National; Biodiversity Institute: Pretoria, South Africa, 2013; pp. 1-139.

8. Eriksen, J.; Ledgard, S.; Lou, J.; Schils, R.; Rasmussen, J. Environmental Impacts of Grazed Pastures. Grassl. Sci. Eur. 2010, 15, 880-890. Available online: https://orgprints.org/id/eprint/17879/4/17879.pdf (accessed on 15 October 2021).

9. Clementini, C.; Pomente, A.; Latini, D.; Kanamaru, H.; Vuolo, M.R.; Heureux, A.; Fujisawa, M.; Schiavon, G.; Del Frate, F. Long-Term Grass Biomass Estimation of Pastures from Satellite Data. Remote Sens. 2020, 12, 2160. [CrossRef]

10. de la Fuente, B.; Weynants, M.; Bertzky, B.; Delli, G.; Mandrici, A.; Garcia Bendito, E.; Dubois, G. Land productivity dynam-ics in and around protected areas globally from 1999 to 2013. PLoS ONE 2020, 15, e0224958. [CrossRef]

11. Le, Q.B.; Nkonya, E.; Mirzabaev, A. Biomass productivity-based mapping of global land degradation hotspots. In Economics of Land Degradation and Improvement-A Global Assessment for Sustainable Development; Springer: Cham, Switzerland, 2016; pp. 55-85. ISBN 978-3-319-19167-6.

12. Wang, J.; Xiao, X.; Bajgain, R.; Starks, P.; Steiner, J.; Doughty, R.B.; Chang, Q. Estimating leaf area index and aboveground biomass of grazing pastures using Sentinel-1, Sentinel-2 and Landsat images. ISPRS J. Photogramm. Remote Sens. 2019, 154, 189-201. [CrossRef]

13. Dabrowska-Zielinska, K.; Budzynska, M.; Gatkowska, M.; Kowalik, W.; Bartold, M.; Kiryla, M. Importance of grasslands monitoring applying optical and radar satellite data in perspective of changing climate. In Proceedings of the 2017 IEEE International Geoscience and Remote Sensing Symposium (IGARSS), Fort Worth, TX, USA, 23 July 2017; pp. 5782-5785. [CrossRef]

14. Symeonakis, E.; Calvo-Cases, A.; Arnau-Rosalen, E. Land use change and land degradation in south eastern Mediterranean Spain. Environ. Manag. 2007, 40, 80-94. [CrossRef]

15. Xu, H.; Huang, X.; Zhong, T.; Chen, Z.; Yu, J. Chinese land policies and farmers' adoption of organic fertilizer for saline soils Land Use Policy 2014, 38, 541-549. [CrossRef]

16. Galdino, S.; Sano, E.E.; Andrade, R.G.; Grego, C.R.; Nogueira, S.F.; Bragantini, C.; Flosi, A.H. Large-scale modeling of soil erosion with RUSLE for conservationist planning of degraded cultivated Brazilian pastures. Land Degrad. Dev. 2016, 27, 773-784. [CrossRef]

17. Truter, W.F.; Botha, P.R.; Dannhauser, C.S.; Maasdorp, B.V.; Miles, N.; Smith, A.; Snyman, H.A.; Tainton, N.M. Southern African pasture and forage science entering the 21st century: Past to present. Afr. J. Range Forage Sci. 2015, 32, 73-89. [CrossRef]

18. Mirzabaev, A.; Goedecke, J.; Dubovyk, O.; Djanibekov, U.; Le, Q.B.; Aw-Hassan, A. Economics of land degradation in Central Asia. In Economics of Land Degradation and Improvement-A Global Assessment for Sustainable Development; Springer: Cham, Switzerland, 2016; pp. 261-290, ISBN 978-3-319-19167-6.

19. Nkonya, E.; Mirzabaev, A.; Von Braun, J. Economics of Land Degradation and Improvement-A Global Assessment for Sustainable Development; Springer: Cham, Switzerland, 2016; ISBN 978-3-319-19167-6.

20. Kwon, H.Y.; Nkonya, E.; Johnson, T.; Graw, V.; Kato, E.; Kihiu, E. Global estimates of the impacts of grassland degradation on livestock productivity from 2001 to 2011. In Economics of Land Degradation and Improvement-A Global Assessment for Sustainable Development; Springer: Cham, Switzerland, 2016; pp. 197-214, ISBN 978-3-319-19167-6.

21. Sevov, A.; Yancheva, C.; Kazakova, Y. Sustainable Pasture Management. In New Perspectives in Forage Crops; InTech: London, UK, 2018.

22. Dingaan, M.N.; Tsubo, M. Improved assessment of pasture availability in semi-arid grassland of South Africa. Environ. Monit. Assess. 2019, 191, 1-2. [CrossRef] [PubMed]

23. Numata, I.; Roberts, D.A.; Chadwick, O.A.; Schimel, J.; Sampaio, F.R.; Leonidas, F.C.; Soares, J.V. Characterization of pasture biophysical properties and the impact of grazing intensity using remotely sensed data. Remote Sens. Environ. 2007, 109, 314-327. [CrossRef]

24. Weber, D.; Schaepman-Strub, G.; Ecker, K. Predicting habitat quality of protected dry grasslands using Landsat NDVI phenology. Ecol. Indic. 2018, 91, 447-460. [CrossRef] 
25. Lugassi, R.; Zaady, E.; Goldshleger, N.; Shoshany, M.; Chudnovsky, A. Spatial and temporal monitoring of pasture ecological quality: Sentinel-2-based estimation of crude protein and neutral detergent fiber contents. Remote Sens. 2019, 11, 799. [CrossRef]

26. Afuye, G.A.; Kalumba, A.M.; Orimoloye, I.R. Characterisation of Vegetation Response to Climate Change: A Review. Sustainability 2021, 13, 7265. [CrossRef]

27. Gibson, D.J.; Newman, J.A. Grasslands and climate change: An overview. In Grasslands and Climate Change; Cambridge University Press: Cambridge, UK, 2019; pp. 3-18, ISBN 978-1-107-19526-4.

28. Cobon, D.H.; Kouadio, L.; Mushtaq, S.; Jarvis, C.; Carter, J.; Stone, G.; Davis, P. Evaluating the shifts in rainfall and pasture-growth variabilities across the pastoral zone of Australia during 1910-2010. Crop Pasture Sci. 2019, 70, 634-647. [CrossRef]

29. Afuye, G.A.; Ojeh, V.N.; Okunlola, B.A.; Adejokun, V.F. Heat-Sum Calculation in Forecasting Maize PhenologicalStages and Harvesting Date in Lagos South West, Nigeria. J. Geogr. Environ. Earth Sci. Int. 2018, 1, 1-2. [CrossRef]

30. Lai, L.; Kumar, S. A global meta-analysis of livestock grazing impacts on soil properties. PLoS ONE 2020, 15, e0236638. [CrossRef]

31. Calotă, A.M.; Pătru-Stupariu, I. Quantifying the effects of defective planning on pastures using urbanization and landscape indicators. In Proceedings of the 10th IALE World Congress-Nature and Society Facing the Anthropocene Challenges and Perspectives for Landscape Ecology, Bucharest, Romania, 1-5 July 2019.

32. Gankhuyag, U. Quantitative Analysis of the Relationship between Mining and Livestock Sectors in Mongolia. Master's Thesis, Columbia University, New York, NY, USA, 2013. [CrossRef]

33. Guo, S.; Jiang, L.; Shen, G.Q. Embodied pasture land use change in China 2000-2015: From the perspective of globalization. Land Use Policy 2019, 82, 476-485. [CrossRef]

34. Thornley, J.H.; Cannell, M.G. Temperate grassland responses to climate change: An analysis using the Hurley pasture model. Ann. Bot. 1997, 80, 205-221. [CrossRef]

35. Johnson, I.R.; Chapman, D.F.; Snow, V.O.; Eckard, R.J.; Parsons, A.J.; Lambert, M.G.; Cullen, B.R. DairyMod and EcoMod: Biophysical pasture-simulation models for Australia and NewZealand. Aust. J. Exp. Agric. 2008, 48, 621-631. [CrossRef]

36. Stolter, C.; Ramoelo, A.; Kesch, K.; Madibela, O.R.; Cho, M.A.; Joubert, D.F. Forage quality and availability for large herbivores in southern African rangelands. Biodivers. Ecol. 2018, 6, 187-196. [CrossRef]

37. Dos Reis, A.A.; Werner, J.P.; Silva, B.C.; Figueiredo, G.K.; Antunes, J.F.; Esquerdo, J.C.; Coutinho, A.C.; Lamparelli, R.A.; Rocha, J.V.; Magalhães, P.S. Monitoring pasture aboveground biomass and canopy height in an integrated crop-livestock system using textural information from PlanetScope imagery. Remote Sens. 2020, 12, 2534. [CrossRef]

38. Segarra, J.; Buchaillot, M.L.; Araus, J.L.; Kefauver, S.C. Remote sensing for precision agriculture: Sentinel-2 improved features and applications. Agronomy 2020, 10, 641. [CrossRef]

39. Mashaba-Munghemezulu, Z.; Chirima, G.J.; Munghemezulu, C. Delineating Smallholder Maize Farms from Sentinel-1 Coupled with Sentinel-2 Data Using Machine Learning. Sustainability 2021, 13, 4728. [CrossRef]

40. Abdel-Hamid, A.; Dubovyk, O.; Graw, V.; Greve, K. Assessing the impact of drought stress on grasslands using multi-temporal SAR data of Sentinel-1: A case study in Eastern Cape, South Africa. Eur. J. Remote Sens. 2020, 53 (Suppl. S2), 3-16. [CrossRef]

41. Chen, Y.; Guerschman, J.; Shendryk, Y.; Henry, D.; Harrison, M.T. Estimating Pasture Biomass Using Sentinel-2 Imagery and Machine Learning. Remote Sens. 2021, 13, 603. [CrossRef]

42. Khiste, G.P.; Paithankar, R.R. Analysis of Bibliometric term in Scopus. Int. J. Libr. Sci. Inf. Manag. 2017, 3, 81-88.

43. Mair, L.; Mill, A.C.; Robertson, P.A.; Rushton, S.P.; Shirley, M.D.; Rodriguez, J.P.; McGowan, P.J. The contribution of scientific research to conservation planning. Biol. Conserv. 2018, 223, 82-96. [CrossRef]

44. Jiang, M.; Huo, Y.; Huang, K.; Li, M. Way forward for straw burning pollution research: A bibliometric analysis during $1972-2016$. Environ. Sci. Pollut. Res. 2019, 26, 13948-13962. [CrossRef] [PubMed]

45. Gao, Y.; Wang, F.; Song, Y.; Liu, H. The status of and trends in the pharmacology of berberine: A bibliometric review. Chin. Med. 2020, 15, 1-3. [CrossRef] [PubMed]

46. Mishra, M.; Sudarsan, D.; Santos, C.A.; Mishra, S.K.; Kar, D.; Baral, K.; Pattnaik, N. An overview of research on natural resources and indigenous communities: A bibliometric analysis based on Scopus database (1979-2020). Environ. Monit. Assess. 2021, 193, 1-7. [CrossRef] [PubMed]

47. Mongeon, P.; Paul-Hus, A. The journal coverage of Web of Science and Scopus: A comparative analysis. Scientometrics 2016, 106, 213-228. [CrossRef]

48. Radhakrishnan, S.; Erbis, S.; Isaacs, J.A.; Kamarthi, S. Novel keyword co-occurrence network-based methods to foster systematic reviews of scientific literature. PLoS ONE 2017, 12, e0172778. [CrossRef]

49. Aria, M.; Cuccurullo, C. Bibliometrix: An R-tool for comprehensive science mapping analysis. J. Informetr. 2017, 11, 959-975. [CrossRef]

50. Linnenluecke, M.K.; Marrone, M.; Singh, A.K. Conducting systematic literature reviews and bibliometric analyses. Aust. J. Manag. 2020, 45, 175-194. [CrossRef]

51. Vieira, A.F.; Moura, M.; Silva, L. Soil metagenomics in grasslands and forests-A review and bibliometric analysis. Appl. Soil Ecol. 2021, 167, 104047. [CrossRef]

52. Orimoloye, I.R.; Ololade, O.O. Global trends assessment of environmental health degradation studies from 1990 to 2018. Environ. Dev. Sustain. 2021, 23, 3251-3264. [CrossRef]

53. Chen, H.; Ho, Y.S. Highly cited articles in biomass research: A bibliometric analysis. Renew. Sustain. Energy Rev. 2015, 49, 12-20. [CrossRef] 
54. Zhou, P.; Tijssen, R.; Leydesdorff, L. University-Industry Collaboration in China and the USA: A bibliometric comparison. PLoS ONE 2016, 11, e0165277. [CrossRef] [PubMed]

55. Yang, J.N.; Shen, Y.Y.; Wang, Y.R. A bibliometric analysis of international grassland agroecology research. Acta Pratacult. Sin. 2017, 26, 224-234. [CrossRef]

56. Yu, D.; Xu, Z.; Wang, W. Bibliometric analysis of fuzzy theory research in China: A 30-year perspective. Knowl.-Based Syst. 2018, 141, 188-199. [CrossRef]

57. Busayo, E.T.; Kalumba, A.M.; Afuye, G.A.; Ekundayo, O.Y.; Orimoloye, I.R. Assessment of the Sendai framework for disaster risk reduction studies since 2015. Int. J. Disaster Risk Reduct. 2020, 50, 101906. [CrossRef]

58. Tang, Y.; Long, X.; Wu, M.; Yang, S.; Gao, N.; Xu, B.; Dutta, S. Bibliometric review of research trends on disinfection by-products in drinking water during 1975-2018. Sep. Purif. Technol. 2020, 241, 116741. [CrossRef]

59. Singh, R.; Sibi, P.S.; Sharma, P.; Tamang, M.; Singh, A.K. Twenty years of journal of quality assurance in hospitality \& tourism: A bibliometric assessment. J. Qual. Assur. Hosp. Tour. 2021, 1-26. [CrossRef]

60. Afuye, G.A.; Kalumba, A.M.; Busayo, E.T.; Orimoloye, I.R. A Bibliometric Review of Vegetation Response to Climate Change. Environ. Sci. Pollut. Res. 2021, 1-13. [CrossRef] [PubMed]

61. Cuccurullo, C.; Aria, M.; Sarto, F. Foundations and trends in performance management. A twenty-five years bibliometric analysis in business and public administration domains. Scientometrics 2016, 108, 595-611. [CrossRef]

62. Zhang, Y.; Huang, K.; Yu, Y.; Yang, B. Mapping of water footprint research: A bibliometric analysis during 2006-2015. J. Clean. Prod. 2017, 149, 70-79. [CrossRef]

63. Van Eck, N.J.; Waltman, L. Software survey: VOSviewer, a computer program for bibliometric mapping. Scientometrics 2010, 84, 523-538. [CrossRef] [PubMed]

64. Van Eck, N.J.; Waltman, L. VOSviewer Manual; Leiden Univeristeit: Leiden, The Netherlands, 2013; pp. 1-53.

65. Moral Muñoz, J.A.; Herrera Viedma, E.; Santisteban Espejo, A.; Cobo, M.J. Software tools for conducting bibliometric analysis in science: An up-to-date review. Prof. Inf. 2020, 29, e290103. [CrossRef]

66. Cobo, M.J.; López-Herrera, A.G.; Herrera-Viedma, E.; Herrera, F. Science mapping software tools:.Review, analysis, and cooperative study among tools. J. Am. Soc. Inf. Sci. Technol. 2011, 62, 1382-1402. [CrossRef]

67. Perianes-Rodriguez, A.; Waltman, L.; Van Eck, N.J. Constructing bibliometric networks: A comparison between full and fractional counting. J. Informetr. 2016, 10, 1178-1195. [CrossRef]

68. Leung, X.Y.; Sun, J.; Bai, B. Bibliometrics of social media research: A co-citation and co-word. Int. J. Hosp. Manag. 2017, 66, 35-45. [CrossRef]

69. Muritala, B.A.; Sánchez-Rebull, M.V.; Hernández-Lara, A.B. A Bibliometric Analysis of Online Reviews Research in Tourism and Hospitality. Sustainability 2020, 12, 9977. [CrossRef]

70. Gagolewski, M. Bibliometric impact assessment with R and the CITAN package. J. Informetr. 2011, 1, 678-692. [CrossRef]

71. Ellegaard, O.; Wallin, J.A. The bibliometric analysis of scholarly production: How great is the impact? Scientometrics 2015, 105, 1809-1831. [CrossRef]

72. Huang, J.; Tang, J.; Qu, Y.; Zhang, L.; Zhou, Y.; Bao, S.; Mu, D. Mapping the knowledge structure of neonatal hypoxic-ischemic encephalopathy over the past decade: A co-word analysis based on keywords. J. Child Neurol. 2016, 31, 797-803. [CrossRef] [PubMed]

73. Barnett, A.G.; Graves, N.; Clarke, P.; Blakely, T. What Is the Impact of Research Funding on Research? Productivity? Available online: eprints.qut.edu.au/83127/ (accessed on 6 November 2021).

74. Saygitov, R.T. The Impact of Grant Funding on the Publication Activity of Awarded Applicants: A Systematic Review of Comparative Studies and Meta-Analytical Estimates. bioRxiv 2018, 1, 354662. [CrossRef]

75. Xie, H.; Zhang, Y.; Wu, Z.; Lv, T. A Bibliometric Analysis on Land Degradation: Current Status, Development, and Future Directions. Land 2020, 9, 28. [CrossRef]

76. Brown, M.E.; Pinzón, J.E.; Didan, K.; Morisette, J.T.; Tucker, C.J. Evaluation of the consistency of long-term NDVI time series derived from AVHRR, SPOT-vegetation, SeaWiFS, MODIS, and Landsat ETM+ sensors. IEEE Trans. Geosci. Remote Sens. 2006, 44, 1787-1793. [CrossRef]

77. Drusch, M.; Del Bello, U.; Carlier, S.; Colin, O.; Fernandez, V.; Gascon, F.; Hoersch, B.; Isola, C.; Laberinti, P.; Martimort, P.; et al. Sentinel-2: ESA's optical high-resolution mission for GMES operational services. Remote Sens. Environ. 2012, $120,25-36$. [CrossRef]

78. Jia, K.; Liang, S.; Gu, X.; Baret, F.; Wei, X.; Wang, X.; Yao, Y.; Yang, L.; Li, Y. Fractional vegetation cover estimation algorithm for Chinese GF-1 wide-field view data. Remote Sens. Environ. 2016, 177, 184-191. [CrossRef]

79. Jacob, F.; Petitcolin, F.; Schmugge, T.; Vermote, E.; French, A.; Ogawa, K. Comparison of land surface emissivity and radiometric temperature derived from MODIS and ASTER sensors. Remote Sens. Environ. 2004, 90, 137-152. [CrossRef]

80. Duchemin, B.; Hadria, R.; Erraki, S.; Boulet, G.; Maisongrande, P.; Chehbouni, A.; Escadafal, R.; Ezzahar, J.; Hoedjes, J.C.; Kharrou, M.H.; et al. Monitoring wheat phenology and irrigation in Central Morocco: On the use of relationships between evapotranspiration, crops coefficients, leaf area index and remotely-sensed vegetation indices. Agric. Water Manag. 2006, $79,1-27$. [CrossRef] 
81. Koetz, B.; Sun, G.; Morsdorf, F.; Ranson, K.J.; Kneubühler, M.; Itten, K.; Allgöwer, B. Fusion of imaging spectrometer and LIDAR data over combined radiative transfer models for forest canopy characterization. Remote Sens. Environ. 2007, 106, 449-459. [CrossRef]

82. De Rosa, D.; Basso, B.; Fasiolo, M.; Friedl, J.; Fulkerson, B.; Grace, P.R.; Rowlings, D.W. Predicting pasture biomass using a statistical model and machine learning algorithm implemented with remotely sensed imagery. Comput. Electron. Agric. 2021, 180, 105880. [CrossRef]

83. Kaufman, Y.J.; Tanré, D. Algorithm for Remote Sensing of Tropospheric Aerosol from MODIS; MODIS Algorithm Theoretical Basis Document; NASA Goddard Space Flight Center: Greenbelt, MD, USA, 1998; Volume 85, pp. 3-68.

84. Covello, F.; Battazza, F.; Coletta, A.; Lopinto, E.; Fiorentino, C.; Pietranera, L.; Valentini, G.; Zoffoli, S. COSMO-SkyMed an existing opportunity for observing the Earth. J. Geodyn. 2010, 49, 171-180. [CrossRef]

85. Nativi, S.; Mazzetti, P.; Santoro, M.; Papeschi, F.; Craglia, M.; Ochiai, O. Big data challenges in building the global earth observation system of systems. Environ. Model. Softw. 2015, 68, 1-26. [CrossRef]

86. Liang, S.H.; Croitoru, A.; Tao, C.V. A distributed geospatial infrastructure for Sensor Web. Comput. Geosci. 2005, 31, 221-231 [CrossRef]

87. Reich, P.B.; Turner, D.P.; Bolstad, P. An approach to spatially distributed modeling of net primary production (NPP) at the landscape scale and its application in validation of EOS NPP products. Remote Sens. Environ. 1999, 70, 69-81. [CrossRef]

88. Anderson, K.; Ryan, B.; Sonntag, W.; Kavvada, A.; Friedl, L. Earth observation in service of the 2030 Agenda for Sustainable Development. Geo-Spat. Inf. Sci. 2017, 20, 77-96. [CrossRef]

89. Kahle, A.B.; Palluconi, F.D.; Hook, S.J.; Realmuto, V.J.; Bothwell, G. The advanced spaceborne thermal emission and reflectance radiometer (ASTER). Int. J. Imaging Syst. Technol. 1991, 3, 144-156. [CrossRef]

90. Cohen, W.B.; Justice, C.O. Validating Modis Terrestrial Ecology Products: Linking in Situ and Satellite Measurements; Elsevier Science Inc.: New York, NY, USA, 1999. [CrossRef]

91. Guanter, L.; Segl, K.; Kaufmann, H. Simulation of optical remote-sensing scenes with application to the EnMAP hyperspectral mission. IEEE Trans. Geosci. Remote Sens. 2009, 47, 2340-2351. [CrossRef]

92. Chuvieco, E.; Li, J.; Yang, X. Advances in Earth Observation of Global Change; Springer: New York, NY, USA, 2010 ; pp. 1-15. [CrossRef]

93. Mineart, G.M.; Crout, R.L. Technologies for global observations of ocean constituents. Mar. Technol. Soc. J. 2005, 39, 36-48. [CrossRef]

94. Pandit, S.; Tsuyuki, S.; Dube, T. Estimating above-ground biomass in sub-tropical buffer zone community forests, Nepal, using Sentinel 2 data. Remote Sens. 2018, 10, 601. [CrossRef]

95. Reida, J.B.; Wood, D. Interactive Model for Assessing Mangrove Health, Ecosystem Services, Policy Consequences, and Satellite Design in Rio de Janeiro Using Earth Observation Data. In Proceedings of the 71st International Astronautical Congress (IAC), International Astronautical Federation, Washington, DC, USA, 12-14 October 2020. Available online: https://hdl.handle.net/1721.1/129598 (accessed on 1 October 2021).

96. Susanty, A.; Bakhtiar, A.; Prasetya, F.; Maher, H.; Setiawan, J.D.; Chiou, C.C.; Wood, D. Indicators for Measuring the Impact of COVID-19 on Supply Chain Vulnerability of SMEs. In Proceedings of the 2021 IEEE 8th International Conference on Industrial Engineering and Applications (ICIEA), Chengdu, China, 23 April 2021; pp. 439-443. [CrossRef]

97. Xia, J.; Yang, C.; Li, Q. Building a spatiotemporal index for earth observation big data. Int. J. Appl. Earth Obs. Geoinf. 2018, 73, 245-252. [CrossRef]

98. Bovée, M. African Nations over the Moon. Ecofin Agency. 2019. Rwanda Ready to Launch another Satellite into Orbit. 2017. Available online: https:/ /www.ecofinagency.com/telecom/1705-40069-Rwanda-ready-to-launch-another-satellite-into-orbit (accessed on 14 July 2021).

99. Woldai, T. The status of Earth Observation (EO) \& Geo-Information Sciences in Africa-trends and challenges. Geo-Spat. Inf. Sci. 2020, 23, 107-123. [CrossRef]

100. Cracknell, A.P. The development of remote sensing in the last 40 years. Int. J. Remote Sens. 2018, 39, 8387-8427. [CrossRef]

101. Amedjar, M. Random Forest Effectiveness for Bragança Region Mapping: Comparing Indices, Number of the Decision Trees, and Generalization. Ph.D. Thesis, Biblioteca Digital do IPB, Braganza, Portugal, 2020.

102. Crabbe, R.A.; Lamb, D.; Edwards, C. Discrimination of species composition types of a grazed pasture landscape using Sentinel-1 and Sentinel-2 data. Int. J. Appl. Earth Obs. Geoinf. 2020, 84, 101978. [CrossRef] 